\title{
Models of Hybrid Springs for Ergonomic Seats and Mattresses
}

\section{Modeli hibridnih opruga za ergonomska sjedala i madrace}

\author{
Original scientific paper • Izvorni znanstveni rad \\ Received-prispjelo: 9. 4. 2012. \\ Accepted-prihvaćeno: 15. 11. 2012. \\ UDK: $630 * 836.1$ \\ doi:10.5552/drind.2013.1230
}

\begin{abstract}
An ergonomic seat or mattress has to provide optimal and uniform support for the body of a man or a woman with similar or slightly differing size centiles. It is a common opinion that spring systems in upholstered furniture are much more durable and more user-friendly than foam systems. The aim of this study was to develop a new construction of an upholstery spring of bilinear stiffness. On the basis of the conducted studies and analysis of their results, it was shown that traditional bonnell and barrel springs exhibit linear stiffness within the range of deflections of up to $70 \%$ of their initial pitch. New spring designs change stiffness already at deflections of $34 \%$ of their pitch. Thanks to this fact they may be used in designs of seats and mattresses for individual users, patients or disabled individuals.
\end{abstract}

Keywords: ergonomics, hybrid spring, mattress, numerical analysis, seat, stiffness

SAŽETAK・Ergonomsko sjedište ili madrac mora osigurati optimalnu i ujednačenu potporu za tijelo muškarca ili žene sličnih ili neznatno različitih veličina. Uobičajeno je mišljenje da su opružni sustavi ojastučenog namještaja mnogo izdržljiviji i prilagodljiviji korisniku nego sustavi od pjene. Cilj je ovog rada bio razviti novu konstrukciju ojastučenog namještaja s oprugama bilinearne krutosti. Na temelju provedenih istraživanja i analiza dobivenih rezultata zabilježeno je da tradicionalne bonnell i barrel opruge pokazuju linearnu krutost u rasponu progiba do $70 \%$ od početnog stanja. Opruge nove izvedbe mijenjaju krutost već pri progibu od $34 \%$ od početnog stanja. Zahvaljujući toj činjenici, mogu se upotrebljavati u dizajniranju sjedala i madraca za pojedinačne korisnike, pacijente ili invalidne osobe.

\section{Ključne riječi: ergonomija, hibridne opruge, madrac, numerička analiza, sjedalo, krutost}

\section{INTRODUCTION}

\section{UVOD}

Functional cushions and mattresses of upholstered furniture should provide the highest comfort of use, since they belong to the group of furniture, with which users have direct contact 14 to 18 hours a day. Thus an ergonomic seat or mattress has to provide optimal and uniform support for the body of a man or a woman with similar or slightly differing size centiles. Among the comfort-quantifying parameters of seats (and analogously also those of mattresses), the ones most frequently cited are: the average human/seat contact pressure, the maximum human/seat contact pressure, the human/ seat contact-area size and the extent of symmetry of the human/seat contact-area (Ebe and Griffin, 2001; Grujicic et al., 2009; Kamijo et al., 1982; Lee et al., 1995; Milvojevich et al., 2000; Park and Kim, 1997; Park et al., 1998; Potter et al., 1998; Reed et al., 1991; Tewari and Prasad, 2000; Thakurta et al., 1995; Uenishi et al.,

\footnotetext{
${ }^{1}$ Author is professor at Department of Furniture Design, Faculty of Wood Technology, Poznan University of Life Sciences, Poznan, Poland.

${ }^{1}$ Autor je profesor Odjela za dizajn namještaja Fakulteta drvne tehnologije, Sveučilište bioloških znanosti, Poznanj, Poljska.
} 
2000; Yun et al., 1992; Zhao et al., 1994). This comfort depends on the type of material used in the manufacture of seats. It is commonly and justly believed that spring systems in upholstered furniture are much more durable and more user-friendly in use than foam systems. However, a majority of literature items are research studies discussing mainly problems of selection, modeling and analyses of stiffness of foam systems in seats of upholstered furniture (Chow and Odell, 1994; Ebe and Griffin, 2001; Ferrarin et al., 2000; Gonga and Kyriakidesa, 2005; Grujicic et al., 2009; Linder-Ganz et al., 2005; Lusiak and Smardzewski, 2010; Silber et al., 2010; Schrodt et al., 2005; Smardzewski et al., 2008, 2010a,b; Smardzewski and Wiaderek, 2007; Vlaovic et al., 2008; Wiaderek and Smardzewski, 2010a,b) or modeling of new foam materials exhibiting auxetic properties (Alderson and Alderson, 2007; Bezazi and Scarpa, 2007, 2009; Brandel and Lakes, 2001; Choi and Lakes, 1992; Lakes, 1987, 1992; Prtre et al., 2006; Scarpa et al., 2004; Webber, 2008). It was repeatedly stressed in those studies that high comfort of use in case of seats and mattresses is ensured thanks to the application of materials with non-linear, progressive stiffness characteristics. Such characteristics result in a situation when, at slight loads, seats are very soft, they are subjected to considerable deflections and, when in contact with the body of the user, generate slight contact stresses. At increasing loads, the same seats increase their stiffness due to unproportional reduction of deflections. At the same time they equalize mean contact stress at the contact zone with the user's body (Chu, 2000; Smardzewski, 2009; Smardzewski et al., 2005, 2006; Smardzewski and Grbac, 1998; Smardzewski and Matwiej, 2007; Verver et al., 2004; Wang and Lakes, 2004; Wiaderek and Smardzewski, 2008). However, there is a lack of a wider discussion on the necessity of changes in shapes and stiffness characteristics of springs or spring panels. Several papers were devoted to this problem, indicating the need to replace springs of linear stiffness characteristics with progressive springs (Dzięgielewski and Smardzewski, 1995; Kapica and Smardzewski, 1994; Smardzewski, 1993a,b,c, 2006, 2008a,b, 2009; Smardzewski and Matwiej, 2006). These changes are required due to anthropotechnical aspects, imposing the necessity to take into consideration individual needs of healthy and disabled persons (Ambrose, 2004; Smardzewski, 2009; Smardzewski et al., 2005, 2010a; Vlaovic et al., 2008; Winkler, 2005).

The aim of this study was to develop virtual (numerical) models of new construction of an upholstery spring of bilinear stiffness to be used in seats and mattresses for users of different weight, height and physique. Such springs should be characterized by slight stiffness at small loads and high stiffness at large loads.

\section{METHODS AND MATERIALS}

\section{METODE I MATERIJALI}

In traditional mattresses, sofas or armchairs, panels composed of bonnell biconical springs or barrel springs placed in autonomic pockets are commonly

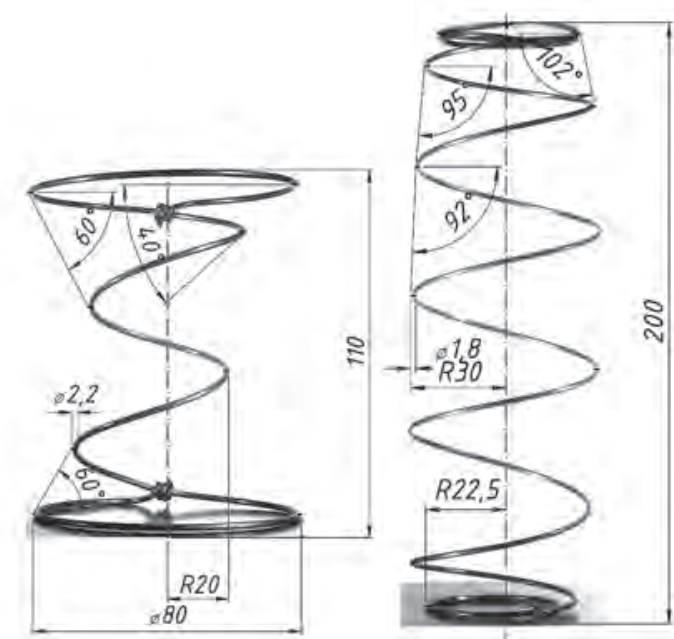

a)

b)

Figure 1 Geometry of traditional upholstery springs: a) bonnell, b) barrel

Slika 1. Geometrija tradicionalnih opruga ojastučenog namještaja: a) bonnell, b) barrel

used. They differ in pitch, diameters of inner and outer coils, the number and pitch of coils as well as the diameter of wire from which they were manufactured (Fig.1). Prior to the design process of new spring designs, it was decided to determine stiffness characteristics of springs presented in Figure 1. Springs were manufactured by a Polish mattress producer. A batch of 10 springs was selected from each type of springs for the uniaxial compression test. Testing was performed on a Zwick 1445 testing machine at $100 \mathrm{~mm} / \mathrm{min}$. load velocity. During the tests load forces were recorded accurate to $0.01 \mathrm{~N}$ and deflections were recorded accurate to $0.01 \mathrm{~mm}$. Loading was interrupted at the deflection of $80 \mathrm{~mm}$ in case of bonnell springs and $150 \mathrm{~mm}$ for barrel springs. On the basis of evaluation of the recorded compression characteristics, bonnell springs were selected for further tests. It was also decided to verify how contact stress distribution changes at the contact of a child's body and the body of an adult with a mattress made from the above mentioned bonnell springs.

Using bonnell springs with the geometry presented in Figure 1a, a mattress of 150 × 900 x 2000 mm was manufactured in a Polish mattress factory. The mattress contained a spring core of $10 \times 24$ springs. The spring core was covered on both sides with felt of $5 \mathrm{~mm}$ in thickness and polyurethane foam T2535 of $20 \mathrm{~mm}$ in thickness, density of $25 \mathrm{~kg} / \mathrm{m}^{3}$ and stiffness of $3.5 \mathrm{kPa}$. The upholstery summer-winter layer on the summer side was made from an upholstery fabric (38\% polyester, $25 \%$ cotton, $37 \%$ polypropylene) quilted with cotton at $200 \mathrm{~g} / \mathrm{m}^{2}$, while on the winter side it was made from an upholstery fabric (46\% polyester, $54 \%$ polypropylene) quilted with natural sheep wool at $250 \mathrm{~g} / \mathrm{m}^{2}$. An FSA Bed sensor mat by Vista Medical, Ltd. was placed on the surface of the summer side of the mattress (sensing area $762 \times 1920 \mathrm{~mm}$, poly thickness $4 \mathrm{~mm}$, sensor dimensions 20.5 x $57.2 \mathrm{~mm}$, sensor gap 3.4 x $3.1 \mathrm{~mm}$, sensor arrangement $32 \times 32$, standard calibration range $13.3 \mathrm{kPa}$ ). It was calibrated prior to measurements and then the mat was coupled with a computer 


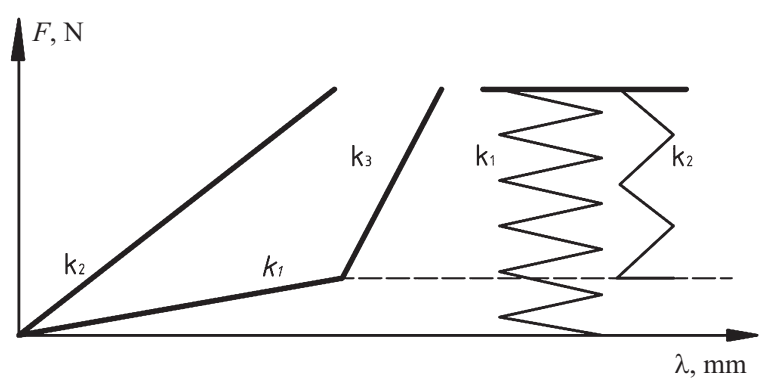

Figure 2 Stiffness of a parallel spring system

Slika 2. Krutost paralelnog sustava opruga

(Intel ${ }^{\circledR}$ Core $^{\mathrm{TM}}$ i5 CPU, $2.53 \mathrm{GHz}, \mathrm{RAM} 4 \mathrm{~GB}$, Windows 7). Load on the mattress was generated by a 3-year old boy of $14.5 \mathrm{~kg}$ and $985 \mathrm{~mm}$ and a 32-year old man of $76 \mathrm{~kg}$ and $1680 \mathrm{~mm}$, both in a lateral recumbent position. Stresses were recorded for each user three times for 5 minutes with a frequency of $10 \mathrm{~Hz}$ and accurate to $0.133 \mathrm{kPa}$. From each measurement a total of $3000 \mathrm{re}-$ cordings were registered. For further analyses the recordings were selected, in which values of maximum stresses changed by max. $10 \%$ in five hundred successive recordings. Taking into consideration the obtained distribution and maximum values of contact stresses on the basis of the discussion of results, new designs of biconical springs were developed.

First, it was decided to design a structure and next to numerically verify stiffness of hybrid springs for seats with non-linear compression characteristics. It was assumed that the designed spring should be composed of two parallel linked elementary springs (Fig. 2). Then, compression characteristics of the whole system would also be composed of two segments, one presenting deflection of the element with stiffness $k_{1}$ to the moment when coils of the spring with stiffness $k_{2}$ settle on the foundation, and the other segment illustrating joint stiffness of both springs with stiffness $k_{3}=k_{1}+k_{2}$.

Traditional parallel systems of cylindrical or barrel springs are of little practical value both from the economic and practical point of view. In such a situation the weight of the box spring and the amount of labor required for its assembly increase. Thus an effective solution needs to be searched for by modeling the stiffness of one-piece hybrid conical springs. Progressive stiffness of the designed springs should provide high softness of the system at mild surface loads and considerable stiffness at the action of concentrated forces or forces of high intensity. For the described operation, conditions the minimum structural requirement is a spring composed of two outer cones with low stiffness and an inner spring (cylindrical or conical) of higher stiffness. The analytical solution for stiffness of conical springs was given for the first time by Timoshenko (Timoshenko and Young, 1962). However, that model may be applied for springs with a small pitch, where the coil angle and distances between coils are slight. In case of bonnell springs, there are large pitches, considerable coil angles and large distances between coils. The calculation method for such springs was presented in studies by Smardzewski (1993,a,b,c, $2006,2008 a, b)$, where stiffness of one spring cone is calculated from the equation:

$$
k=\frac{1}{\frac{4 \cdot m \cdot n}{G \cdot r^{4}\left(R_{2}^{m}-R_{1}^{m}\right)} \int_{0}^{R_{2}-R_{1}} R^{m+2} d R}
$$

Where:

$$
R=\frac{R_{2}^{m}-R_{1}^{m}}{2 \pi n} \cdot \alpha+R_{1}^{m}
$$

$R_{1}$ - the biggest coil radius / najveći polumjer namotaja,

$R_{2}$ - the smallest coil radius / najmanji polumjer namotaja,

$\alpha$ - the angle of the coil spring / kut namotaja opruge,

$n$ - number of spring coils / broj namotaja opruge,

$G$ - Kirchhoff modulus / Kirchhoffov modul,

$r$ - spring wire radius / polumjer žice opruge,

$m$ - coefficient dependent on spring stiffness / koeficijent ovisan o krutosti opruge.

The above mentioned studies also presented the consistency of analytical solutions with the results of numerical calculations. Despite the fact that the developed mathematical formulas adequately describe the stiffness of modeled structures, from the point of view of practice in design offices, it may be difficult to apply. Thus, it was decided to conduct virtual modeling of spring shape in the Autodesk ${ }^{\circledR}$ Inventor ${ }^{\circledR}$ Professional 2011 environment with the use of computer-integrated CAD/CAE applications, well-known and commonly available to engineers. It was assumed that the dimensions of outer spring cones would be close to the dimensions of spring cones from Figure 1a, at: $2 \leq n \leq 4, R_{1}=20 \mathrm{~mm}, R_{2}=40 \mathrm{~mm}, G=9 \cdot 10^{4} \mathrm{MPa}$, $1.4 \leq 2 r \leq 2.2 \mathrm{~mm}$. On this basis, three models of hybrid springs to be used in a furniture seat were prepared with the dimensions as in Figure 3.

The models are characterized by an identical shape of the outer biconical spring. The difference consists in the shape of the 4-coil inner spring. Model A has an inner spring with coils expanding downwards at a $3^{\circ}$ angle. Model $\mathrm{B}$ contains a cylindrical spring with an identical diameter of inner coils, while model $\mathrm{C}$ comprises a conical spring, which coils narrow downwards at an angle of $5^{\circ}$. A constant distance of $34.4 \mathrm{~mm}$ was maintained between the base of the biconical spring and the base of each of the inner springs. This distance results from the adopted assumption that, in case of seat springs within this range of deflections, the stiffness of spring $k_{1} \leq 0.3 \mathrm{~N} / \mathrm{mm}$. This means that deflections amounting to approx. $1 / 3$ pitch of the spring should be caused by loads of max. $10 \mathrm{~N}$.

Each of the designs (a total of 9) was recorded in an STP file and as solids they were imported to the Autodesk ${ }^{\circledR}$ Algor ${ }^{\circledR}$ Professional 2011 system, performing calculations using the finite element method. Next, appropriate meshes were generated, composed of 20-node solid elements with mesh size of max. $0.5 \mathrm{~mm}$ (Fig. 4). Nodes of coils constituting the base of the biconical spring were steadily supported and placed on the Impact Plane surface. This surface made it possible to provide a comprehensive analysis of contact with all surfaces of spring coils. Compression loads were exerted by a stiff 


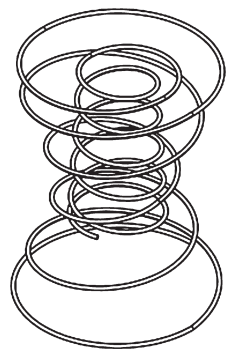

a)

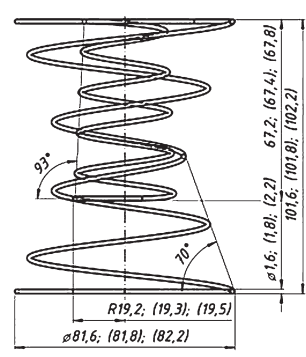

b)

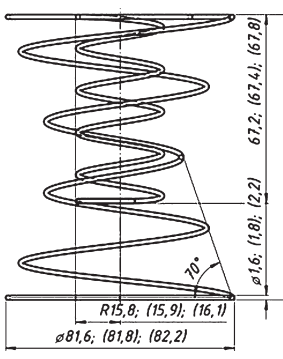

c)

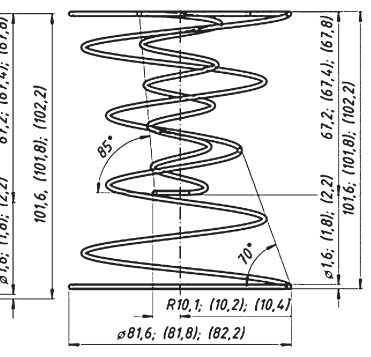

)

Figure 3 Geometry of hybrid springs type: a) A, b) B, c) C

Slika 3. Geometrija hibridnih opruga tipa: a) A, b) B, c) C

plate $\left(E=2 \cdot 10^{5} \mathrm{MPa}\right)$ placed over the upper spring coils. Moreover, the master and slave surfaces were defined for all plate-spring coil pairs in contact during compression. The plate was steadily supported in the horizontal plane providing freedom of movement in the vertical axis. Surface loads with the total value of $57.04 \mathrm{~N}$ were applied onto the upper plate surface, corresponding to the value of compressive force of a bonnell spring during the experimental tests.

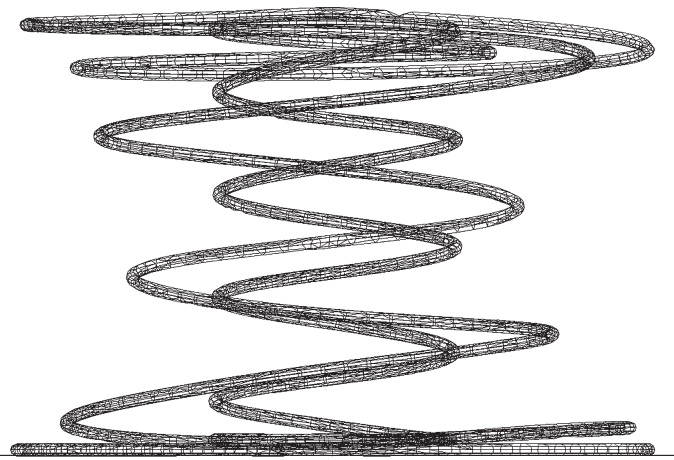

Figure 4 Mesh model of spring

Slika 4. Mrežasti model opruge

The wire material was spring steel with the modulus of elasticity $E=9 \cdot 10^{4} \mathrm{MPa}$. The task was defined as nonlinear taking into consideration considerable displacements, realizing 100 iterations within 1 second. As a result of calculation, stiffness characteristics were obtained for individual hybrid springs, and they were presented in the form of the dependence force $=f($ displacement $)$.

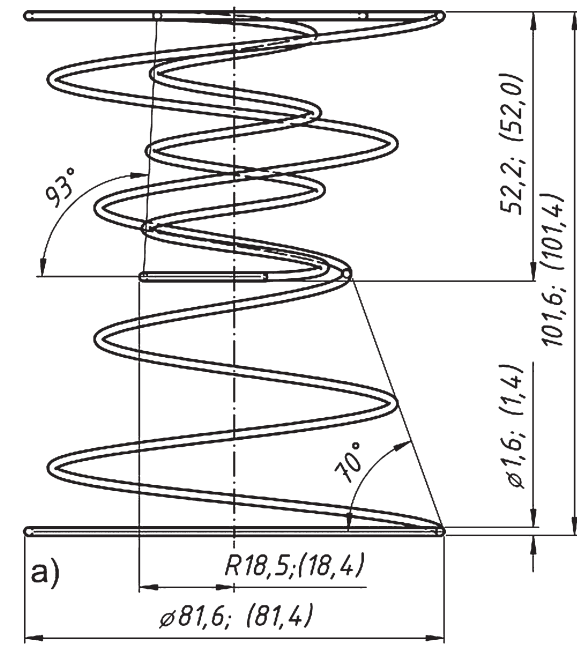

The next step in the design process was to develop a spring structure with a non-linear compression characteristic, to be used in mattresses. Here the assumed spring stiffness was $k_{1} \leq 0.2 \mathrm{~N} / \mathrm{mm}$. This means that deflection of approx. $1 / 2$ pitch of a biconical spring should be caused by loads of max. 10 N. In view of the above recommendations, four successive spring designs were prepared with geometry and dimensions as in Figure 5. Wire with a diameter of 1.4 and $1.6 \mathrm{~mm}$ was used in the models. Model D is characterized by an identical shape of the outer biconical spring as that in models A, B and C. The difference consisted in the shape of the inner spring. This spring was composed of three coils expanding downwards at an angle of $3^{\circ}$. In model E, the geometry of the outer biconical spring was changed. The coil angle was increased from $70^{\circ}$ to $75^{\circ}$, while the coil angle of the inner spring changed from $3^{\circ}$ to $6^{\circ}$. Moreover, the distance between the base of the biconical spring and the base of each of the inner springs was increased to $50 \mathrm{~mm}$. This distance was to provide greater free settlement of coils in the biconical spring than in the previous models. The method of preparation for numerical calculation in models $\mathrm{D}$ and E was identical as in case of models A, B and C.

\section{RESULTS AND DISCUSSION} 3. REZULTATI I RASPRAVA

Uniaxial compression of conical and barrel springs indicates a completely different character of

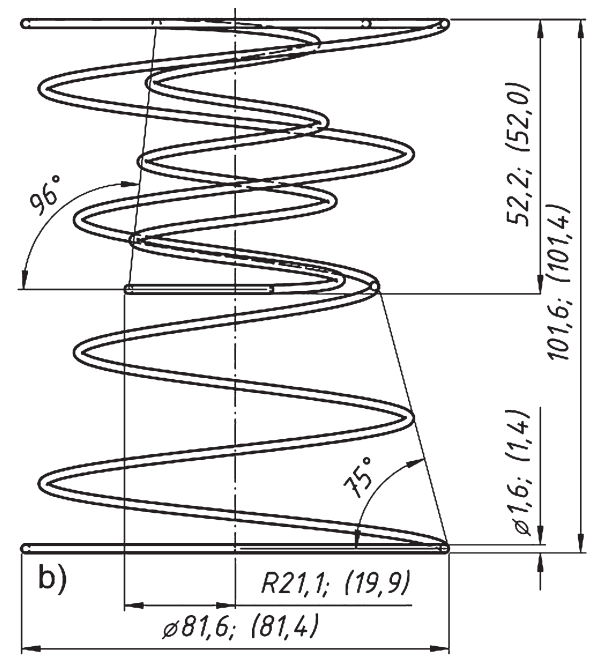

Figure 5 Geometry of hybrid biconical springs type: a) D, b) E, made from wire with a diameter of 1.4 or $1.6 \mathrm{~mm}$ Slika 5. Geometrija hibridnih bikoničnih opruga tipa: a) D, b) E, napravljena od žice promjera 1,4 ili 1,6 mm 


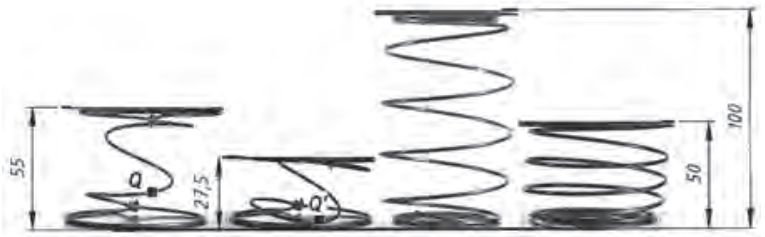

a)

b)

Figure 6 Geometry of deformed upholstery springs: a) bonnell, b) barrel springs

Slika 6. Geometrija deformirane opruge za ojastučeni namještaj: a) bonnell opruge, b) barrel opruge

work for each of these springs. Figure 6 presents forms of deformation for springs compressed to $50 \%$ and 25 $\%$ of their initial pitch. As it can be seen in Figure 6a, coils of bonnell springs defectively settle onto the base within the range of deflections of approx. $3 / 4$ of spring pitch. Only when this boundary was exceeded, the first active coil settled on the base and it was only in one point Q. In case of a barrel spring (Fig. 6b), the gradual settlement of coils occurs only at a deflection exceeding $75 \%$ of spring pitch.

Settlement of coils at such a considerable compression of springs results in a situation when their range of progression is practically shifted outside the range of design work. Figure 7 presents mean stiffness characteristics of bonnell and barrel springs determined in the uniaxial compression test. It can be clearly seen from this figure that within the range of displacements of up to $70 \mathrm{~mm}$, a bonnell spring exhibits a linear dependence between force and deflection. Only when this value is exceeded, spring stiffness increases markedly. It is caused by the above mentioned settlement of coils and its support on the base. In contrast, a barrel spring exhibits a much lower, but instead completely linear stiffness characteristic.

Linearity of the design load section of compression characteristics in both springs results in a situation when the same mattress made from identical components and with identical dimensions may be too hard for a child and too soft for an adult. This is indicated by the results of measurements shown in Figure 8. It can be seen that the greatest contact stresses at the contact surface of the boy's body and the mattress concentrate at the head, the shoulder and the pelvis (Fig. 8a). At the site of support for the shoulder its maximum value was $8.79 \mathrm{kPa}$, while at the support site for the pelvis it was $9.86 \mathrm{kPa}$. At the body/mattress contact surface in case of the man, the greatest stresses were recorded at the height of the shoulder and head amounting to 12.13 $\mathrm{kPa}$, while at the support site for the pelvis, stresses amounted to $6.79 \mathrm{kPa}$.

Guttmann (1946), Husain (1953) and Kosiak $(1959,1961)$ reported a relationship between the amount of pressure, duration of application and the development of tissue damage in canine and rat experiments. Kosiak $(1959,1961)$ stated that microscopic pathological changes were noted in tissues subjected to as little as $8 \mathrm{kPa}$ for only one hour, although no changes were recorded in the animals that were subjected to pressures of $4.7 \mathrm{kPa}$ for periods up to four hours. According to Hostensa et al. (2001), Landis (1930), Takahashi et al. (2010) pressures lower than 2.7 to $4 \mathrm{kPa}$ are required to prevent capillary occlusion and pressure discomfort due to prolonged sitting. Reswick and Rogers (1976) developed a relationship between the maximum pressure being experienced by the supporting tissues and the time over which that maximum pressure was applied. If the pressure/time index fell above the curve, subjects exhibited pressure sore histories. If it fell in the acceptable zone, they did not show pressure problems. This classic study has served as the basis for clinical management practices until this day.

Loads of $4-8 \mathrm{kPa}$, as a criterion for comfort, were applied in many studies on designs of seats and mattresses (Brienza et al., 1996; Butcher and Thompson, 2009, 2010; Gross et al., 1994; Hamanami et al., 2004; Sacks, 1989; Seigler and Ahmadian, 2003; Smardzewski, 2009; Smardzewski et al., 2010a,b; Tewari and Prasad, 2000; Wang et al., 2004). On the basis of the presented literature data and those from Figure 8, it can be seen that the selected mattress was too hard for the user of a small weight, having a small body/ mattress contact surface area. Also the man's body was inadequately supported. A too high disproportion of stresses in the shoulder and pelvis areas indicates that

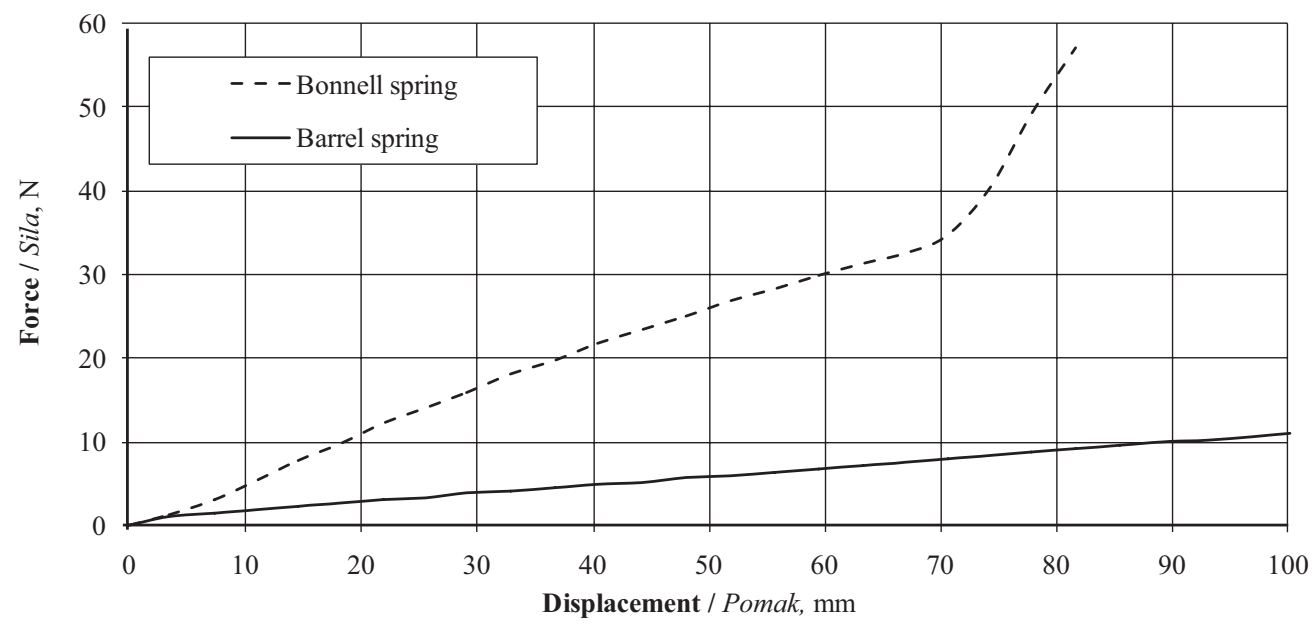

Figure 7 Stiffness of springs in the uniaxial compression test

Slika 7. Krutost opruga pri jednoosnome tlačnom ispitivanju 


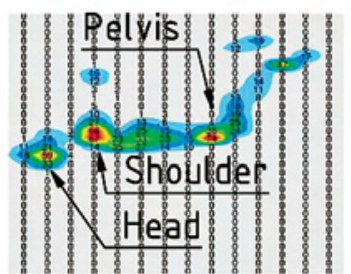

a)

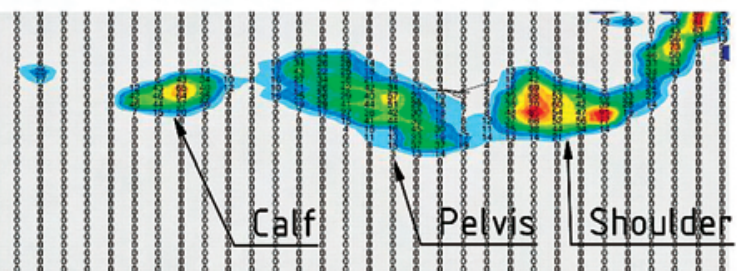

b) $q_{\max }=12.13 \mathrm{kPa}$

Figure 8 Distribution of contact stresses on the contact surface of the user's body with the mattress: a) a child, b) a man Slika 8. Raspodjela kontaktnih naprezanja na dodirnoj površini korisnikova tijela i madraca: a) dijete, b) muškarac

springs of a linear stiffness, as those applied in the mattress, press too intensively on the shoulder and moderately on the pelvis.

In view of the above, designs for new, nonlinear springs - type A, B and C were prepared, whose calculated stiffness characteristics are shown in Figures 9, 10 and 11.

When comparing stiffness of springs modeled from wire with a diameter of $1.6 \mathrm{~mm}$ (Fig. 9), it can be seen that within the range of displacements from 0 to $34.4 \mathrm{~mm}$ only the biconical spring works. Its stiffness in this range of displacements overlaps with stiffness of the barrel spring. From the moment of contact of the first coils of the inner spring with the base stiffness, the whole system increases markedly. Here, the smallest slope of the curve was observed for model A, while it was the greatest for model $\mathrm{C}$. This means that above a load of $7 \mathrm{~N}$, deflections of the spring type A increase faster than those of spring type B, while deflections of spring type B increment faster than deflections of spring $\mathrm{C}$. The two-rate nonlinear stiffness of springs results in a situation when, at a load of $20 \mathrm{~N}$, a traditional bonnell spring deflects by $37 \mathrm{~mm}$, spring type A by $48 \mathrm{~mm}$, spring B by $45 \mathrm{~mm}$, while spring $\mathrm{C}$ by 41 $\mathrm{mm}$, respectively. An increase in load up to $40 \mathrm{~N}$ causes the bonnell spring to continue to deflect linearly to the value of $74 \mathrm{~mm}$, while spring A to $69 \mathrm{~mm}$, spring B to $60 \mathrm{~mm}$ and spring $\mathrm{C}$ to $52 \mathrm{~mm}$. In order to better describe differences in stiffness of springs, two stiffness coefficients were defined. Coefficient $k_{1}=\left(F_{7 \mathrm{~N}^{-}}\right.$

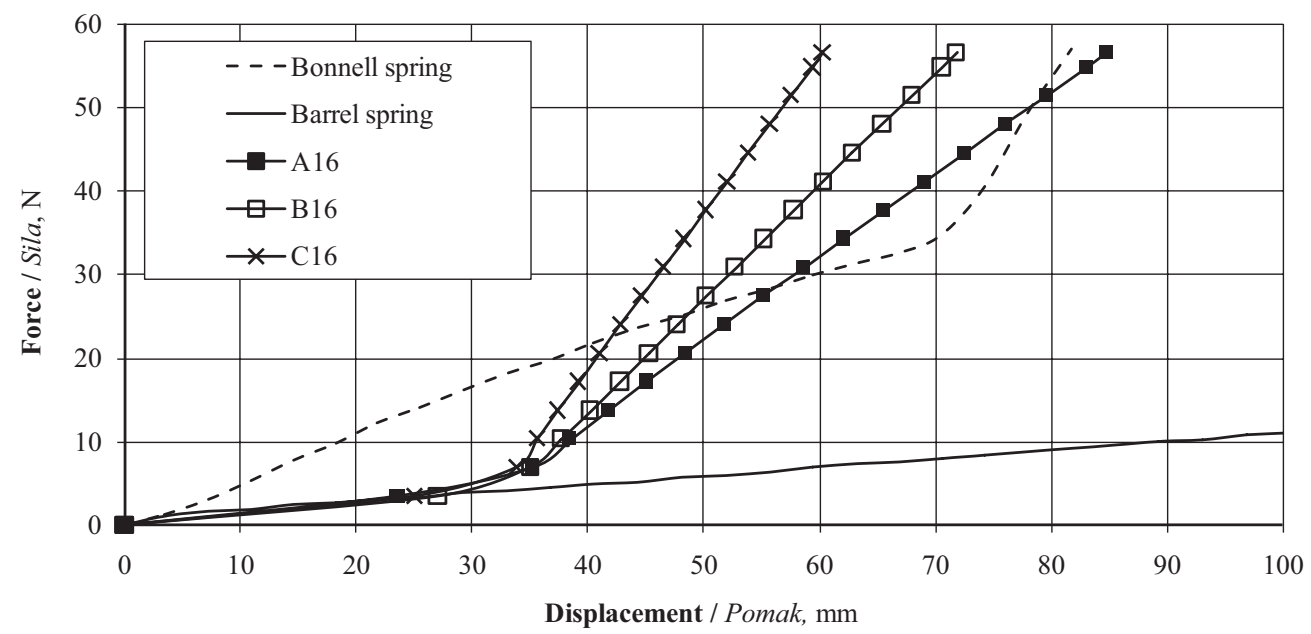

Figure 9 Stiffness of hybrid upholstery springs made from wire with a diameter of $1.6 \mathrm{~mm}$ Slika 9. Krutost hibridnih opruga za ojastučeni namještaj napravljenih od žice promjera 1,6 mm

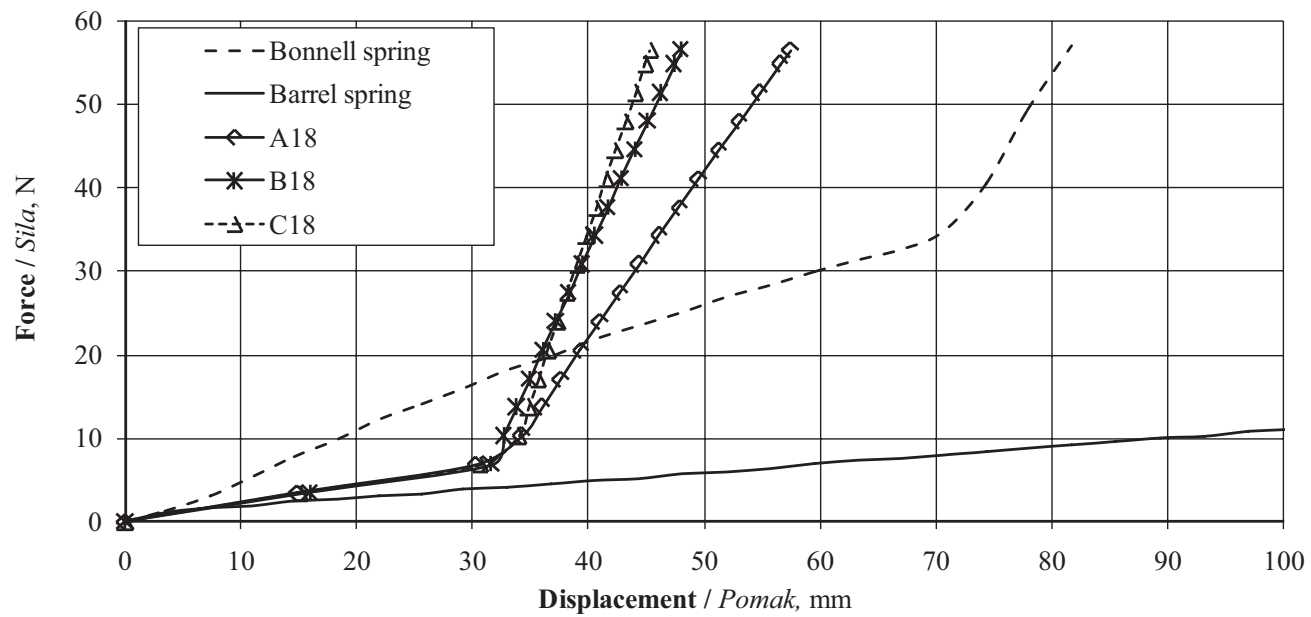

Figure 10 Stiffness of hybrid upholstery springs made from wire with a diameter of $1.8 \mathrm{~mm}$

Slika 10. Krutost hibridnih opruga za ojastučeni namještaj napravljenih od žice promjera $1,8 \mathrm{~mm}$ 


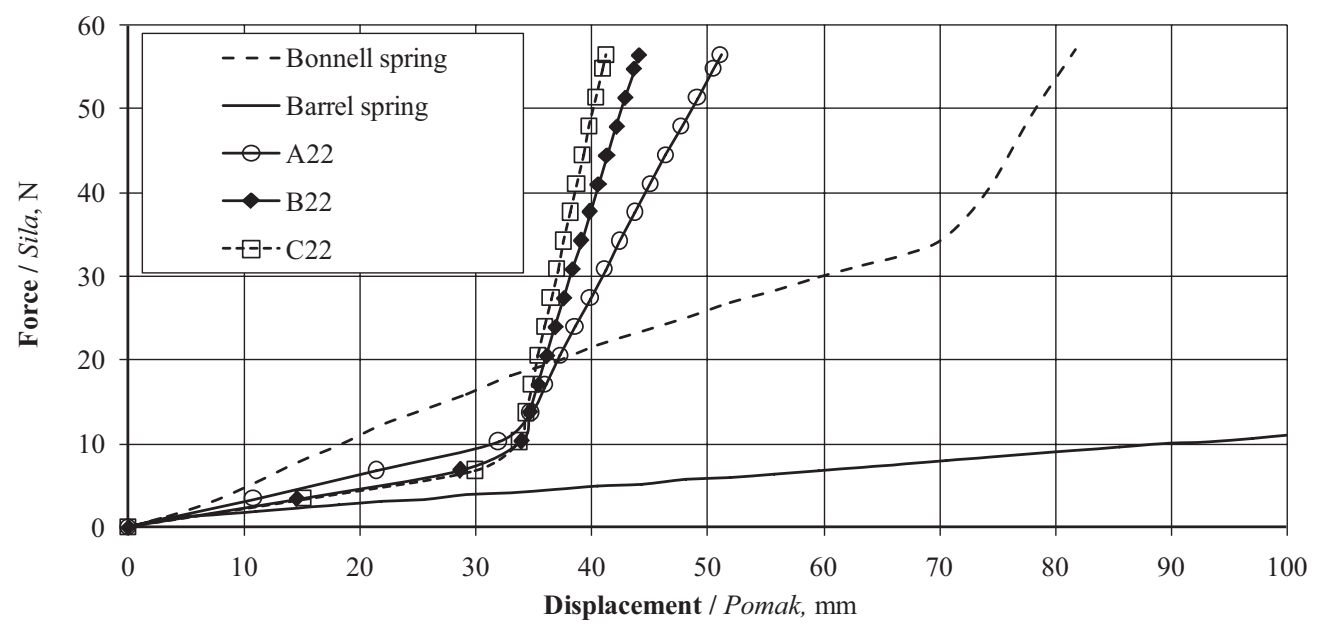

Figure 11 Stiffness of hybrid upholstery springs made from wire with a diameter of $2.2 \mathrm{~mm}$

Slika 11. Krutost hibridnih opruga za ojastučeni namještaj napravljenih od žice promjera 2,2 mm

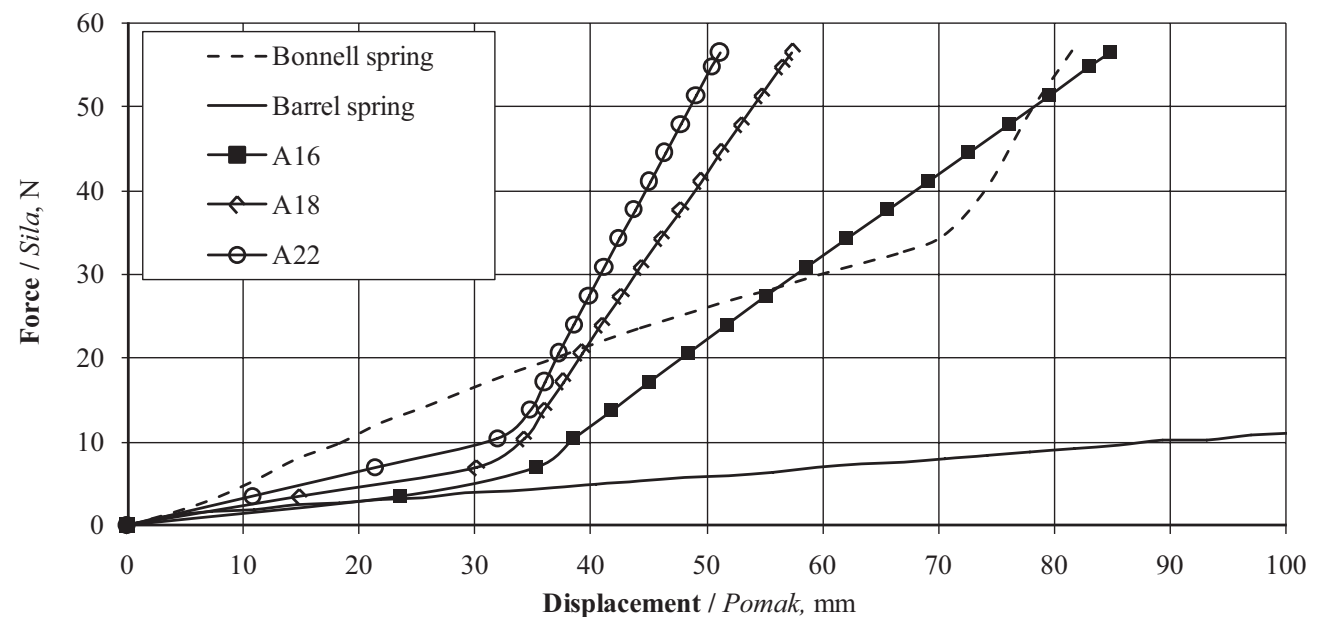

Figure 12 Stiffness of hybrid upholstery springs type A

Slika 12. Krutost hibridnih opruga za ojastučeni namještaj tipa A

$\left.F_{0 \mathrm{~N}}\right) /\left(\lambda_{7 \mathrm{~N}}-\lambda_{0 \mathrm{~N}}\right)(\mathrm{N} / \mathrm{mm})$ for the first linear segment of the characteristic with a maximum load of $7 \mathrm{~N}$ and $k_{3}=\left(F_{40 \mathrm{~N}}-F_{10 \mathrm{~N}}\right) /\left(\lambda_{40 \mathrm{~N}}-\lambda_{10 \mathrm{~N}}\right)(\mathrm{N} / \mathrm{mm})$ for the second segment, illustrating stiffness resultant from the outer biconical spring and the inner spring, with the maximum load of 40 N. As it can be seen from Figure 9, stiffness of the barrel spring is constant, amounting to $k_{1}=0.11$ $\mathrm{N} / \mathrm{mm}$, while it is $k_{1}=0.55 \mathrm{~N} / \mathrm{mm}$ for the bonnell spring. Still stiffness of all models of hybrid springs in the first range is $0.19<k_{1(\mathrm{~A}, \mathrm{~B}, \mathrm{C})}<0.20 \mathrm{~N} / \mathrm{mm}$. In the second range of deflections, stiffness depends on the shape of the inner spring. For spring type A, the stiffness index $k_{3 \mathrm{~A}}$ is $0.99 \mathrm{~N} / \mathrm{mm}$, for spring $\mathrm{B} k_{3 \mathrm{~B}}=1.36 \mathrm{~N} /$ $\mathrm{mm}$, and for spring type $\mathrm{C} k_{3 \mathrm{C}}=1.87 \mathrm{~N} / \mathrm{mm}$.

Stiffness of springs modeled from wire with a diameter of $1.8 \mathrm{~mm}$ and $2.2 \mathrm{~mm}$ is presented in Figures 10 and 11 . Also in these cases similar qualitative differences can be observed in stiffness of individual spring models. It is also of interest that their stiffness in the first range of displacements increased slightly. For models made from wire with a diameter of $1.8 \mathrm{~mm}$, this stiffness falls within the range of $0.22<k_{1(\mathrm{~A}, \mathrm{~B}, \mathrm{C})}<0.23 \mathrm{~N} /$ $\mathrm{mm}$, while for models made from wire with a diameter of $2.2 \mathrm{~mm}$, it is $0.23<k_{1(\mathrm{~A}, \mathrm{~B}, \mathrm{C})}<0.32 \mathrm{~N} / \mathrm{mm}$. Considerably greater quantitative differences are found in the second range of displacements, during the simultane- ous compression of coils in the biconical and inner springs. As it can be seen in Figure 10, the stiffness index for individual springs is as follows: $k_{3 \mathrm{~A}}=2.01$, $k_{3 \mathrm{~B}}=3.04$ and $k_{3 \mathrm{C}}=4.11 \mathrm{~N} / \mathrm{mm}$. In turn, for springs made from wire with a diameter of $2.2 \mathrm{~mm}$ (Fig.11), stiffness indexes for individual spring types are ordered as follows: $k_{3 \mathrm{~A}}=2.63, k_{3 \mathrm{~B}}=4.57, k_{3 \mathrm{C}}=6.26 \mathrm{~N} / \mathrm{mm}$.

Taking into consideration the results of numerical calculations, it is obvious that the new models of upholstery springs in terms of their performance characteristics are much more attractive in comparison to bonnel or barrel (encased) springs used so far. A significant advantage of these springs is connected with their two-rate stiffness guaranteeing a greater potential for free modeling of stiffness in seats of armchairs depending on the needs of their users. Considering their anthropometric properties, particularly weight and dimensions of the body, a seat optimally supporting the body in the sitting position should be designed. Among the nine analyzed variants of springs, model A made from wire with a diameter of 1.6, 1.8 and $2.2 \mathrm{~mm}$ turned out to be the most practical structural solution. Advisability of this selection is confirmed by Figure 12. It can be seen from this figure that, when applying different wire diameters, the stiffness of springs in the initial range of coil settlement may easily be changed from $0.19 \mathrm{~N} / \mathrm{mm}$ to $0.32 \mathrm{~N} / \mathrm{mm}$. 


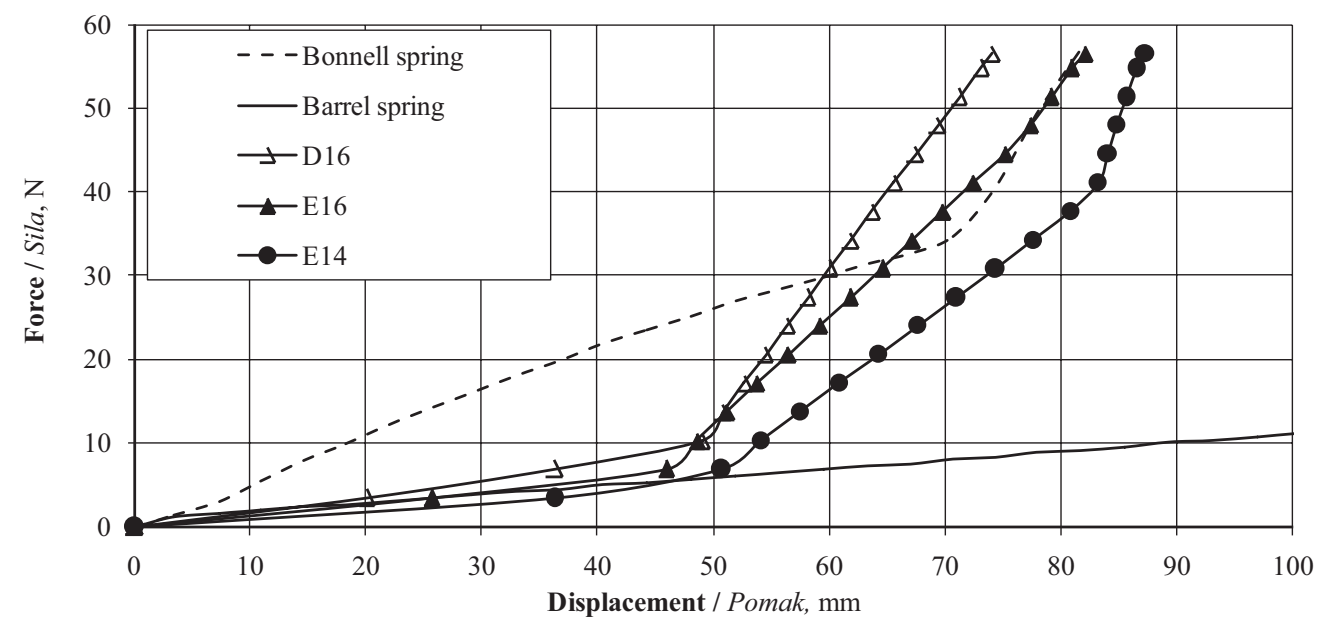

Figure 13 Stiffness of hybrid upholstery springs type D and E

Slika 13. Krutost hibridnih opruga za ojastučeni namještaj tipa D i E

In the second range of the experiment parameters, their stiffness increases from $0.99 \mathrm{~N} / \mathrm{mm}$ to $2.63 \mathrm{~N} / \mathrm{mm}$. Thus, in terms of such a spectrum of spring stiffness, a structural solution may be selected, aimed at providing comfort and functionality to seating and resting furniture to a child, a woman or to a man. Due to their linear stiffness characteristics (Fig. 12), bonnell or barrel springs do not ensure such extensive possibilities.

Moreover, new designs were also developed for spring type D and E to be used in mattresses. Their nonlinear stiffness characteristics are presented in Figure 13, including characteristics of spring type D made from wire with a diameter of $1.6 \mathrm{~mm}$ and two characteristics of spring type E made from wire with a diameter of 1.4 and $1.6 \mathrm{~mm}$.

We can see from Fig. 13 that the settlement of coils in the inner spring starts after the spring is compressed by approx. $50 \mathrm{~mm}$. Here, depending on the spring model and wire diameter, the value of force causing this settlement varies. For spring type D this force was $10 \mathrm{~N}$, while for spring type $\mathrm{E} 7 \mathrm{~N}$ or $8 \mathrm{~N}$, depending on the diameter, it was made from i.e. 1.4 $\mathrm{mm}$ vs. $1.6 \mathrm{~mm}$. In the first range of the spring operation, their stiffness was $k_{1 \mathrm{D}}=0.19 \mathrm{~N} / \mathrm{mm}, 0.14<k_{1 \mathrm{E}}<0.15$ $\mathrm{N} / \mathrm{mm}$. It is obviously markedly lower than the stiffness of barrel springs, which is particularly significant in modeling of mattresses to be used by children and women. In the second stage of coil settlement, stiffness resultant from individual springs increased markedly. For spring type E it was $1.85 \mathrm{~N} / \mathrm{mm}$, while for spring type $\mathrm{D}$ made from wire with a diameter of $1.6 \mathrm{~mm}$ $k_{3 \mathrm{E}}=1.28 \mathrm{~N} / \mathrm{mm}$. In case of spring type $\mathrm{E}$ made from wire with a diameter of $1.4 \mathrm{~mm} k_{3 \mathrm{E}}=1.08 \mathrm{~N} / \mathrm{mm}$. Moreover, this spring has an additional advantage. As it can be seen from Figure 13, before complete compression, it exhibits a three-rate stiffness characteristic. In the third range of work its stiffness is $4.18 \mathrm{~N} / \mathrm{mm}$.

The presented models of hybrid springs for mattresses differ from hybrid springs for seats in terms of the following characteristics: they exhibit a greater range of free coil settlement of outer springs, lower stiffness in the first and second range of work during uniaxial compression and in some cases three-stage stiffness characteristics. These advantages perfectly match the modeling of ergonomic mattresses adapted to individual needs of users. It is crucial particularly when the bed should be designed for use in boarding houses, students' hostels, hotels, hospitals, etc., where many individuals of different physique use the same mattress.

\section{CONCLUSIONS}

\section{ZAKLJUČCI}

On the basis of conducted tests and analyses of their results, the following conclusions and observations may be made:

- Traditional bonnell or barrel springs exhibit linear stiffness over a considerable range of design displacements of up to $70 \mathrm{~mm}$,

- Tested mattresses made from bonnell springs by contact with the user's body cause disadvantageous pressures exceeding $8 \mathrm{kPa}$,

- Developed structures of hybrid springs are characterized by an advantageous nonlinear stiffness,

- In the design of seats, we may recommend springs model A made from wire with a diameter from 1.6 $\mathrm{mm}$ to $2.2 \mathrm{~mm}$, while for mattresses we recommend springs type E made from wire with a diameter from 1.4 to $1.6 \mathrm{~mm}$.

\section{REFERENCES}

\section{LITERATURA}

1. Alderson, A.; Alderson, K., 2007: Auxetic materials. Proc. IME G.J. Aero.Eng. 221: 565-575.

2. Ambrose, D.H., 2004: Developing random virtual human motions and risky work behaviors for studying anthropotechnical systems. U.S. Department of Health and Human Services Centers for Disease Control and Prevention, National Institute for Occupational Safety and Health, Pittsburgh Research Laboratory.

3. Autodesk ${ }^{\circledR}$ Inventor ${ }^{\circledR}$ Professional 2011: Help. Autodesk, Inc.

4. Autodesk ${ }^{\circledR}$ Algor ${ }^{\circledR}$ Professional 2011: Help. Autodesk, Inc.

5. Bezazi, A.; Scarpa, F., 2007: Mechanical behavior of conventional and negative Poisson's ratio thermoplastic polyurethane foams under compressive cyclic loading. Int. J. Fatigue. 29: 922-930 http://dx.doi.org/10.1016/j.ijfatigue.2006.07.015. 
6. Bezazi, A.; Scarpa, F., 2009: Tensile fatigue of conventional and negative Poisson's ratio open cell PU foams. Int. J. Fatigue. 31: 488-494

http://dx.doi.org/10.1016/j.ijfatigue.2008.05.005.

7. Brandel, B.; Lakes, R.S., 2001: Negative Poisson's ratio polyethylene foams. J. Mater. Sci. 36: 5885-5893 http://dx.doi.org/10.1023/A:1012928726952.

8. Brienza, D.; Karg, P.; Brubaker, C., 1996: Seat cushion design for elderly wheelchair users based on minimization of soft tissue deformation using stiffness and pressure measurements. IEEE Transactions on Rehabilitation Engineering, 4(4): 320-328 http://dx.doi.org/10.1109/86.547933.

9. Butcher, M.; Thompson, G., 2009: Dressings can prevent pressure ulcers: fact or fallacy? The problem of pressure ulcer prevention. Wounds 5 (4): 80-93.

10. Butcher, M.; Thompson, G., 2010: Can the use of dressing materials actually prevent pressure ulcers: presenting the evidence. Wounds 6 (1): 119-125.

11. Choi, J.B.; Lakes, R.S., 1992: Nonlinear properties of polymer cellular materials with a negative Poisson's ratio. J. Mater. Sci. 27: 4678-4684 http://dx.doi.org/10.1007/BF01166005.

12. Chow, W.W.; Odell, E.I., 1994: Deformations and stress in soft body tissues of sitting person. J. Biomech Eng. 100: 79-87 http://dx.doi.org/10.1115/1.3426196.

13. Chu, S.J., 2000: Finite element analysis of contact stresses between a seat cushion and a human body. Science and Technology, 2000. KORUS 2000. Proceedings. The 4th Korea-Russia International Symposium. 3: 11-16.

14. Dzięgielewski, St.; Smardzewski, J., 1995: Computer evaluation and modeling of upholstered spring systems (in Polish). Komputerowa ocena i modelowanie formatek sprężynowych mebli tapicerowanych. Przemysł Drzewny Rok XLVI 4: 6-12.

15. Ebe, K.; Griffin, M., 2001: Factors affecting static seat cushion. Comfort Ergonomics, 44 (10): 901-921 http://dx.doi.org/10.1080/00140130110064685.

16. Ferrarin, M.; Andreoni, G.; Pedotti, A., 2000: Comparative biomechanical evaluation of different wheelchair seat cushions. Journal of Rehabilitation Research and Development, 37 (3): 315-324.

17. Gonga, L.; Kyriakidesa, S.; Triantafyllidisb, N., 2005: On the stability of Kelvin cell foams under compressive loads. Journal of the Mechanics and Physics of solids, 53: 771-794 http://dx.doi.org/10.1016/j.jmps.2004.10.007.

18. Gross, C.M.; Goonetilleke, R.S.; Menon, K.K.; Banaag, J.C.N.; Nair, C.M., 1994: The biomechanical assessment and prediction of seat comfort. In Lueder, R. and Noro, K. (Eds), Hard Facts About Soft Machines: The ergonomics of seating (London: Taylor \& Francis): 231-253.

19. Grujicic, M.; Pandurangan, B.; Arakere, G.; Bell, W.C.; He, T.; Xie, X., 2009: Seat-cushion and soft-tissue material modeling and a finite element investigation of the seating comfort for passenger-vehicle occupants. Materials and Design 30: 4273-4285

http://dx.doi.org/10.1016/j.matdes.2009.04.028.

20. Guttmann, L., 1946: Rehabilitation after injuries to the spinal cord and cauda equina. Br J Phys Med, 9: 130-137.

21. Hamanami, K.; Tokuhiro, A.; Inoue, H., 2004: Finding the optimal setting of inflated air pressure for a multi-cell air cushion for wheelchair patients with spinal cord injury. Acta Med. Okyama, 58 (1): 37-44.

22. Hostensa, I.; Papaioannoub, G.; Spaepenb, A.; Ramona, H., 2001: Buttock and back pressure distribution tests on seats of mobile agricultural machinery. Applied Ergonomics 32: 347-355 http://dx.doi.org/10.1016/S0003-6870(01)00013-8.

23. Husain, T., 1953: An experimental study of some pressure effects on tissues, with reference to the bed-sore problem. J Pathol Bacteriol, 66 (2): 347-358 http://dx.doi.org/10.1002/path.1700660203.
24. Kamijo, K.; Tsujimura, H.; Obara, H.; Katsumata, M., 1982: Evaluation of seating comfort. In: SAE Conference, No. 820761.

25. Kapica, L.; Smardzewski, J., 1994: Influence of the geometry of dual conical springs on the stiffness of bonnell system (in Polish). Wpływ geometrii sprężyn dwustożkowych stosowanych w formatkach bonnell na ich sztywność. Przemysł Drzewny, Rok XLV 10: 1-3.

26. Kosiak, M., 1959: Etiology and pathology of ischemic ulcers. Arch Phys Med Rehabil, 40 (2): 62-69.

27. Kosiak, M., 1961: Etiology of decubitus ulcers. Arch Phys Med Rehabil, 42: 19-29.

28. Lakes, R.S., 1987: Foam Structures with a Negative Poisson's Ratio. Science. 235: 1038-1040 http://dx.doi.org/10.1126/science.235.4792.1038.

29. Lakes, R.S., 1992: Experimental Micromechanics Method for Conventional and Negative Poisson's Ratio Cellular Solids as Cosserat Continua. J.Eng. Mat. \& Techn. 113: 148-155 http://dx.doi.org/10.1115/1.2903371.

30. Landis, E.M., 1930: Micro-injection studies of capillary blood pressure in human skin. Heart 15: 209-228.

31. Lee, J.; Grohs, T.; Milosic, M., 1995: Evaluation of objective measurement techniques for automotive seat comfort. In: SAE Conference, SAE No. 950142.

32. Linder-Ganz, E.; Yarnitzky, G.; Portnoy, S.; Yizhar, Z.; Gefen, A. 2005: Real-time finite element monitoring of internal. Stress in the bittlok during whellchasir sitting to prevent sores: verification and phantom results. II International Conference on Computational Bioengineering. Lisbon, Portugal, September 14-16.

33. Lusiak, A.; Smardzewski, J., 2010: Creative thinking in designing furniture for pre-school children. Annals of Warsaw University of Life Sciences SGGW, Forestry and Wood Technology 70: 270-278.

34. Milvojevich, A.; Stanciu, R.; Russ, A.; Blair, G.R.; Heumen, J.D., 2000: Investigating psychometric and body pressure distribution responses to automotive seating comfort. In: SAE Conference, SAE No. 2000.

35. Park, S.J.; Kim, C.B., 1997: The evaluation of seating comfort by objective measures. In: SAE Conference, SAE no. 970595.

36. Park, S.J.; Lee, Y.S.; Nahm, Y.E.; Lee, J.W.; Kim, J.S., 1998: Seating physical characteristics and subjective comfort: design considerations. In: SAE Conference, SAE No. 980653.

37. Prtre, M.T.; Erdemir, A.; Cavanagh, P.R., 2006: Determination of elastomeric foam parameters for simulations of complex loading. Computer Methods in Biomechanics and Biomedical Engineering. 9(4): 231-242 http://dx.doi.org/10.1080/10255840600747620.

38. Potter, D.W.; Fortier, C.J.; Rigby, W.A.; Stevenson, J.M., 1998: Development and analysis of a comparative evaluation methodology for office chairs. Proceedings, 30th Annual conference of the human factors association of Canada.

39. Reed, M.P.; Saito, M.; Kakishima, Y.; Lee, N.S.; Schneider, L.W., 1991: An investigation of driver discomfort and related seat design factors in extended-duration driving. In: SAE Conference, SAE No. 910117.

40. Reswick, J.; Rogers, J., 1976: Experience at rancho los amigos hospital with devices and techniques to prevent pressure sores. In Bedsore Biomechanics, Kennedy, Cowden \& Scales (Eds .), Baltimore: University Park Press: 301-310.

41. Sacks, A.H., 1989: Theoretical prediction of a time-atpressure curve for avoiding pressure sore. Journal of Rehabilitation Researchand Development Vol. 26: 27-33.

42. Scarpa, F.; Bullough, W.A.; Lumley, P., 2004: Trends in acoustic properties of iron particle seeded auxetic polyurethane foam. Proc IME CJ Mech. Eng. Sci. 218: 241-244.

43. Schrodt, M.; Benderoth, G.; Kuhhorn, A.; Silber, G., 2005: Hyperelastic Description of Polymer Soft Foams at Finite Deformations. Technische Mechanik, 25(3-4): 162-173. 
44. Seigler, M.; Ahmadian, M., 2003: Evaluation of an alternative seating technology for truck seats. Heavy Vehicle Systems. A Series of the Int. J. of Vehicle Design, 10 (3): 188-208.

45. Silber, G.; Alizadeh, M.; Salimi, M., 2010: Large deformation analysis for soft foams based on hyperelasticity, 26(3): 327-334.

46. Smardzewski, J., 1993a: Stiffness of the dual conical upholstery springs (in Polish). Sztywność dwustożkowych sprężyn tapicerskich. Przemysł Drzewny, Rok XLIV 2: 6-9.

47. Smardzewski, J., 1993b: Ergonomic assessment of the bonnell springs systems (in Polish) Ocena ergonomiczna formatek sprężynowych typu bonnell. Przemysł Drzewny, Rok XLIV 10: 5-7.

48. Smardzewski, J., 1993c: Ergonomic model of springs systems (in Polish). Model ergonomiczny formatki sprężynowej. Przemysł Drzewny, Rok XLIV 11: 6-8.

49. Smardzewski, J., 2006: Specificity of modeling of springs systems for upholstered furniture (in Polish). Specyfika modelowania układów sprężynowych mebli tapicerowanych. Proceedings of the conference, Polioptymalizacja i Komputerowe Wspomaganie Projektowania. Mielno, Poland: 169-177.

50. Smardzewski, J, 2008a: Furniture design. PWRiL Poznan. Chapter 8 pp: 523-591.

51. Smardzewski, J., 2008b: Stiffness modeling of dual conical upholstery spring. Annals of Warsaw University of Life Sciences SGGW, Forest and Wood Technology, 64: 247-252.

52. Smardzewski, J., 2009: Antropotechnical aspects of furniture design. Drvna industrija 60(1): 15-21.

53. Smardzewski, J.; Barańska-Woźny, J.; Wiaderek, K.; Prekrat, S.; Grbac I., 2010a: Mechanical and biomechanical criteria in furniture designing for $60+$ users. Proceedings of the international conference, Wood is good transfer of knowledge in practice as a way out of the crisis. Ambienta, Zagreb, Croatia: 113-122.

54. Smardzewski, J.; Grbac I., 1998: Numerical analysis of ergonomic function of upholstered furniture. Proceedings of the international conference. Ambienta, Zagreb, Croatia: 61-68.

55. Smardzewski, J.; Grbac, I.; Prekrat, S., 2008: Nonlinear mechanics of hyper elastic polyurethane furniture foams. Drvna industrija 59(1): 23-28.

56. Smardzewski, J.; Matwiej, Ł.; Grbac I., 2005: Anthropotechnical models in testing mattress. Electronic Journal of Polish Agricultural Universities, Wood Technology, Volume 8, Issue 3 Available http://www.ejpau.media.pl/volume8/issue3/art-38.html.

57. Smardzewski, J.; Matwiej, Ł., 2006: Rigidity of parallel springs systems in furniture mattresses. Proceedings of the international conference, Calunnickie Dni. Topolcany Slovakia, 126-131.

58. Smardzewski, J.; Matwiej, Ł., 2007: Analysis of the manbed mechanical system. Proceedings of the international conference, Calunnicke Dni, Teoria a prax. Zvolen Slovakia: $42-49$.

59. Smardzewski, J.; Prekrat, S.; Pervan, S., 2010b: Research of Contact Stresses between Seat Cushion and Human Body. Drvna Industrija 61(2): 95-101.

60. Smardzewski, J.; Wiaderek, K.; Grbac I., 2006: Numerical analysis of contact problems of human body and elastic mattress. Proceedings of the international conference European Union - Challenges and perspectives for the woodprocessing industry. Ambienta, Zagreb, Croatia: 81-86.

61. Smardzewski, J.; Wiaderek, K., 2007: The analysis of the human body-seat mechanical system. Proceedings of the international conference, Calunnicke Dni, Teoria a prax. Zvolen, Slovakia: 50-55.

62. Takahashi, M.; Black, J.; Dealey, C.; Gefen, A., 2010: Pressure in context. International review. Pressure ulcer prevention: pressure, shear, friction and microclimate in context. A consensus document. London: Wounds International: $2-10$.

63. Tewari, V.K.; Prasad, N., 2000: Optimum seat pan and back-rest parameters for a comfortable tractor seat. Ergonomics 43(2): 167-186 http://dx.doi.org/10.1080/001401300184549.

64. Timoshenko, S.; Young, D.H., 1962: Elements of Strength of Materials. Van Nostrand Reinhold Company, New York, Cincinnati, Toronto, London, Melbourne, pp:80-81.

65. Thakurta, K.; Koester, D.; Bush, N.; Bachle, S., 1995: Evaluating short and long term seating comfort. In: SAE Conference, SAE no. 950144.

66. Uenishi, K.; Fujihashi, K.; Imai, H., 2000: A seat ride evaluation method for transient vibrations. In: SAE Conference, SAE No. 2000-01-0641.

67. Verver, M.M.; Hoof, J.V.; Oomens, C.W.J.; Wismans, J.S.H.M.; Baaijens, F.P.T., 2004: A Finite Element Model of the Human Buttocks for Prediction of Seat Pressure Distributions, Computer Methods in Biomechanics and Biomedical Engineering, 7(4): 193-203 http://dx.doi.org/10.1080/10255840410001727832.

68. Vlaovic, Z.; Bogner, A.; Grbac, I., 2008: Comfort Evaluation as the Example of Anthropotechnical Furniture Design. Coll. Antropol. 32(1): 277-283.

69. Wang, Y.C.; Lakes, R.S., 2002: Analytical parametric analysis of the contact problem of human buttocks and negative Poisson's ratio foam cushions. International Journal of Solids and Structures 39: 4825-4838 http://dx.doi.org/10.1016/S0020-7683(02)00379-7.

70. Wang, X.; Wang, T.; Jiang, F.; Duan, Y., 2004: A twodimensional modelling for human hip stress analysis. Biomed Eng. Appl. Basis Comm, 16: 32-36 http://dx.doi.org/10.4015/S1016237204000062.

71. Webber, R.S.; Alderson, K.; Evans, K.E., 2008: A novel fabrication route for auxetic polyethylene, part 2: Mechanical properties. Polym. Eng. Sci. 48: 1351-1358 http://dx.doi.org/10.1002/pen.21110.

72. Wiaderek, K.; Smardzewski, J., 2008: Analysis of the contact problem of human thighs and elastic seat cushion. Annals of Warsaw University of Life Sciences SGGW, Forest and Wood Technology, 66: 184-188.

73. Wiaderek, K.; Smardzewski, J., 2010a: Numerical evaluation of seat hardness, Annals of Warsaw University of Life Sciences SGGW, Forestry and Wood Technology 70: 305-311.

74. Wiaderek, K.; Smardzewski, J., 2010b: Modeling of foam seats in terms of comfortable relaxation furniture design. Proceedings of the international conference, Wood is good - transfer of knowledge in practice as a way out of the crisis. Ambienta, Zagreb, Croatia: 139-146.

75. Winkler, T., 2005: Computer Aided Design of Anthropotechnical systems (in Polish). Wydawnictwa NaukowoTechniczne. Warszawa 2005.

76. Yun, M.H.; Donjes, L.; Freivalds, A., 1992: Using force sensitive resistors to evaluate the driver seating comfort. Adv Ind Ergon Safety IV: 403-410.

77. Zhao, L.Q.; Xia, Q.S.; Wu, X.T., 1994: Study of sitting comfort of automotive seats. SAEConference, SAE No. 945243.

\section{Corresponding address:}

Professor JERZY SMARDZEWSKI, Ph.D.

Poznan University of Life Sciences

Faculty of Wood Technology

Department of Furniture Design

Wojska Polskiego 38/42

60-637 Poznan,

POLAND

e-mail: jsmardzewski@up.poznan.pl 